1st International Conference - Global Ethics - Key of Sustainability (GEKoS) | May 15th, 2020 | Bucharest, Romania

\title{
Financial Markets - Under the Sign of CSR. Some Evidences Regarding Financial Education
}

\author{
Mirela PANAIT, Irina RADULESCU, Alina BREZOI \\ https://doi.org/10.18662/lumproc/gekos2020/11
}

How to cite: Panait, M., Radulescu, I., \& Brezoi, A. (2020). Financial Markets - Under the Sign of CSR. Some Evidences Regarding Financial Education. In A. Grigorescu \& V. Radu (vol. ed.), Lumen Proceedings: Vol. 11. 1 st International Conference Global Ethics - Key of Sustainability (GEKoS) (pp. 96106). Iasi, Romania: LUMEN Publishing House.

https://doi.org/10.18662/lumproc/gekos2020/11 


\title{
Financial Markets - Under the Sign of CSR. Some Evidences Regarding Financial Education
}

\author{
Mirela PANAIT ${ }^{1 *}$, Irina RADULESCU ${ }^{2}$, Alina BREZOI ${ }^{3}$
}

\begin{abstract}
The financial market is in a process of metamorphosis, the international crises being determining factors in the reconfiguration process. In addition, the stakeholders attitude reshapes the different components of the financial markets. Financial consumers have become a force that requires financial institutions to adopt honest and ethical behavior. Portfolio investors also sanction, by specific methods, the inappropriate behavior of companies towards the environment or local communities or encourage listed companies that carry out corporate social responsibility (CSR) programs. The stock exchanges and the authorities that supervise and regulate the segments of the financial market are promoters of CSR, both through the power of the example and through specific programs. In this dynamic context, the article aims to carry out an analysis regarding the contribution of financial market actors on promoting the principles of sustainable development and the principles of Global Compact in national economies. The article focuses on the process of financial education in several European countries. The authors identified and analyzed five financial education platforms in selected European countries. The analysis of the statistical data reveals a low interest of financial consumers, especially from the countries from the former communist bloc.
\end{abstract}

Keywords: financial market; CSR; financial education.

\footnotetext{
${ }^{1}$ Petroleum-Gas University of Ploiesti, Romania, mirela.matei@upg-ploiesti.ro

2 Petroleum-Gas University of Ploiesti, Romania, iradulescu@,upg-ploiesti.ro

${ }^{3}$ Petroleum-Gas University of Ploiesti, Romania, alina brezoi@yahoo.com

* Corresponding author.

(C) The Authors, LUMEN Conference Center \& LUMEN Proceedings.

Selection and peer-review under responsibility of the Organizing Committee of the conference
} 


\section{Introduction}

The financing decision on the capital market is no longer taken exclusively on the principle of risk-return, more and more specialists demonstrated, with statistical data, the importance of psychological resources that nuance the selling and buying actions that investors make on the stock exchange [1], [2]. Emotional and psychological forces have a major impact on the capital market and the phenomenon of financial behaviors is studied at an interdisciplinary level by specialists in various fields such as psychology, sociology, anthropology, finance, and economics. Preferences, overconfidence in own abilities, conservatism are elements that influence investors' decisions to trade certain securities on the stock exchange or to act on banking or insurance markets. Moreover, the type of investor - individual or institutional has consequences on behavior, in the sense that individual investors not only have smaller funds, but do not have complex knowledge and do not have enough time and infrastructure to access more complex financial products. In addition, they have a higher inclination towards herd behavior, a fact generated mainly by the precarious endowment with specific knowledge [3]. The entire economic activity is under the sign of innovation, which is also manifested intensely on the financial market, being often an engine of sustainable development [4], [5], [6]. Financial innovation generated by both ethnic progress and the desire of financial institutions to attract new customers, the intensification of competition between banks and stock exchanges has led to the emergence of complex financial products, in some cases, difficult to assess even by rating agencies. In some cases, financial innovation has generated toxic assets, which have been misappropriated and used and fueled or triggered financial crises [7]. Another trend that marks the development of the financial market is digitalization that contributes to market development and increasing financial inclusion [8], [9], [10], [11] by improving the access of vulnerable consumers to products and financial services. On the capital market, the appearance of automated trading programs has generated the intensification of the transactions, usually initiated by the institutional investors who have the possibility to open and close, in a very short period of time, different positions on capital market.

\section{Problem Statement}

Based on these new trends, the authors' scientific approach has focused on the contribution that financial markets to promote the principles of sustainable development. The main tool used in this regard is CSR. More 
and more companies have realized the importance of involvement in society, maximizing profit for shareholders no longer being the only goal of managers [12], [13], [14], [15], [16], [17]. The companies have considerably broadened their vision and horizon of interests, in the sense that they consider, in addition, to consider the interest of other categories of stakeholders such as customers, suppliers. The promotion of CSR through various programs or tools generates positive effects primarily for the company that enjoys a better image among stakeholders, registering an increase in sales and automatically an improvement in financial performance. Companies not only pay attention to the CSR tools used, but also to the way they communicate their specific actions to stakeholders. The activity of reporting non-financial information regarding ESG aspects has acquired new values, in order to maximize the impact of communications on stakeholders [18], [19]. Moreover, the concept of social responsibility has been extended to other categories of economic agents that in this way could contribute to environmental protection, development of local communities, promotion of human rights or the fight against corruption [7].The importance of financial market actors is essential in promoting the concept of CSR given the different categories of stakeholders with whom they interact. Moreover, in various forms and with the help of specific tools, financial institutions directly promote the principles of CSR or can model the behavior of different categories of stakeholders [7], [20], [21], [22], [23]. CSR promotion tools are varied and have a different complexity in the market segment on which they are used. More and more financial products launched on the banking or stock market have integrated various environmental and social aspects, and the use of these tools by investors also gives them the opportunity to get involved in promoting the principles of sustainable development. In this way, banks and stock exchanges also promote the activity of companies that respect in their activity certain principles of CSR or sustainable development, such as those launched by the Global Compact. The launch of sustainability indices or trading markets especially for companies with a certain CSR behavior by the big stock exchanges is a recognition of the involvement of certain companies in promotion of sustainable development [24], [25]. Financial market institutions have a CSR behavior that takes into account the specificities of this field, considering that they do not carry out activities with a negative impact on the environment. For this reason, as a rule, their CSR programs do not address environmental issues, being focused on issues such as promoting cultural and sports activities among young people or people with disabilities, the development of local communities or consumer financial education. 


\section{Aims of the research}

The purpose of the authors' scientific approach is to analyze the phenomenon of financial education specific to some European countries. Financial education has a special importance in the current complex context, that characterizes the financial market. On the one hand, financial products have become increasingly complex and are difficult to understand and evaluate especially by individual investors. On the other hand, the decrease of the confidence of the financial consumers in the credit institutions but also in the actors of the capital market after the triggering of the international or regional financial crises give even more importance to the process of financial education. Increasing life expectancy and living standards intensify the concerns of financial consumers to find appropriate financial instruments to be used to make long-term investment (investment plan for retirement, home purchase) or short-term speculative investment.

\section{Research Methods}

Financial institutions use different communication channels with their clients in order to transmit information on financial products and services offered, but also general knowledge on the process of saving and lending, the realization of a budget, an investment plan. The main tools of financial education identified by the authors by analyzing the sites of different financial institutions are financial education platforms, seminars, conferences and workshops, competitions. The process of financial education is a long process that should begin with the transmission of specialized knowledge to preschool children and continue throughout life given the intensity and complexity of the financial innovation process, the need to make financial decisions at any age. Moreover, in addition to financial institutions and financial supervisors, the financial education programs should also involve the ministry of education that provides the general institutional framework, but also the universities that have partnerships in different financial institutions. In addition, companies, regardless of the object of activity, should initiate and periodically run financial education programs for employees given the long-term emotional impact that a financial decision may have (contracting a real estate loan for a period of 30 years substantially marks the mood of a person, which is reflected in his productivity at work).In the conditions of digitalization of the economy, more and more credit institutions, stock exchanges and brokerage companies offer information through their own sites, having specific sections of Financial Education or have launched in collaboration 
with various entities operating on the financial market, dedicated platforms for education financial. Based on these considerations, the scientific approach of this article is based on the following aspects.

1. Identification of five financial education platforms in Europe (Italy, Greece, Romania, Slovakia, Bulgaria).

2. Analyze the impact of these platforms by using the SEMRUSH web page analysis tool. Traffic analysis targets the country of origin (organic traffic).

3. Analysis period 2012-2020. Given the dynamics of the financial education phenomenon, especially in the case of former members of the communist bloc, many of the financial education platforms appeared after 2012, as can be seen from graphs 1-5 which show the traffic on these platforms.

\section{Findings}

Financial education platforms are instruments usually created by financial institutions, foundations or associations of these institutions, by central banks or banking supervisory authorities with responsibilities in the field of capital markets or insurance market.

Thus, "Fondazione per l'Educazione Finanziaria e al Risparmio" (Italy) which manages the platform is created by the Italian Banking Association. For financial consumers in Italy, the analysis of statistical data reveals a constant interest in banking products and services, a situation specific to Western European countries (graphic 1).

In Greece, the identified financial education platform is administered by the Financial Literacy Institute established in February 2016. The population's interest in financial subjects is low, as can be seen from the analysis of organic traffic shown in graphic 2 .

Graphic 1. Traffic analysis for www.feduf.it [26]

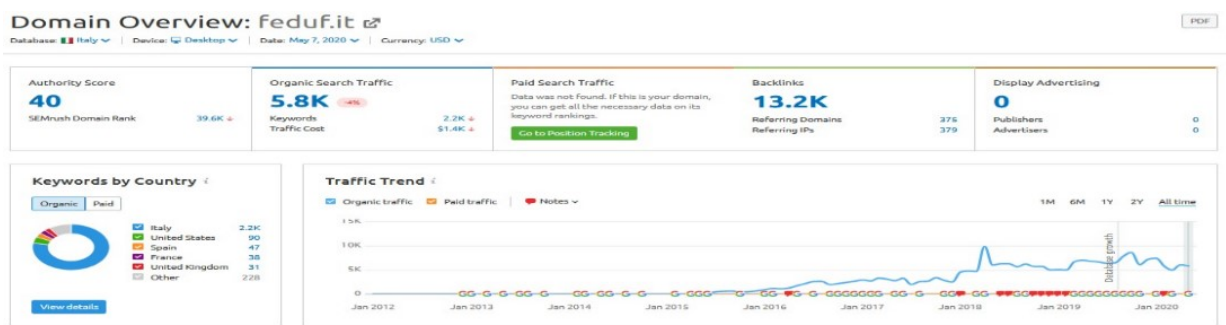

Source: https:// wnw.semrush.com [27] 
Graphic 2. Traffic analysis for https://www.gfli.gr [28]

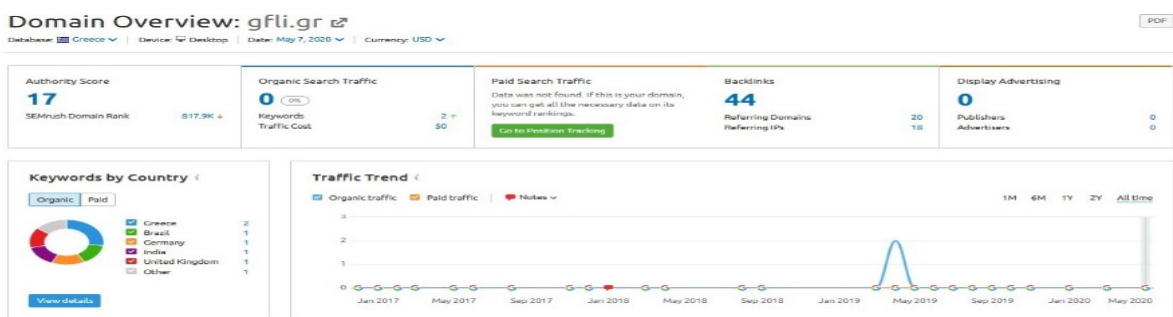

Source: https:// www.semrush.com [27]

In Slovakia, the financial education platform addresses young people in order to prepare them for real life, when they have to make concrete decisions on the financial market either for contacting a loan or for placing savings (graphic 3).

The philosophy of the financial education programs initiated on this platform is based on the three IQs that an individual must have, namely intelligence and emotional quotient and financial culture quotient - FinQ.(IQ $+\mathrm{EQ}+\mathrm{FinQ}=3 \mathrm{Q}$ for life $)$.

Graphic 3. Traffic analysis https://www.finq.sk [29]

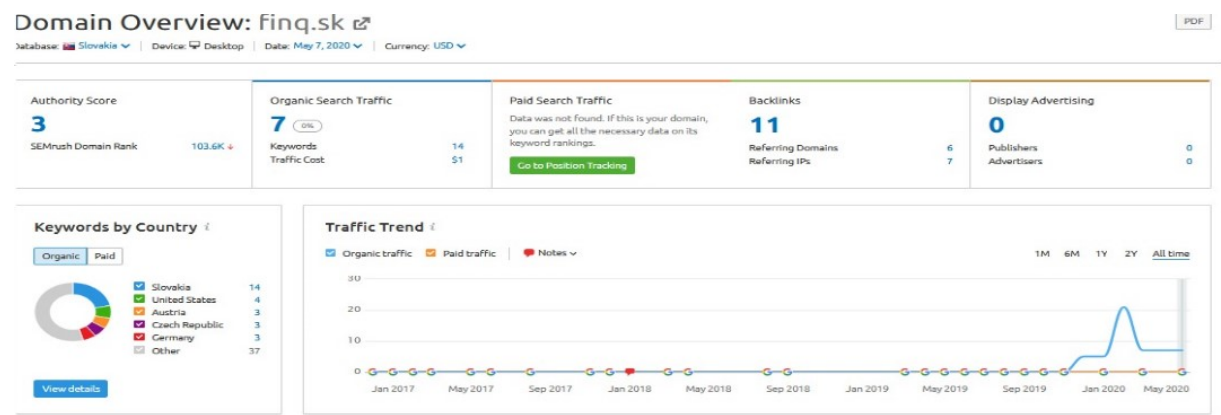

Source: https:// www.semrush.com [27]

In the case of Romania, there is a growing interest of financial consumers who access different sections of the platform (graphic 4). The main countries of origin of consumers that are interested in financial topics are the USA, Romania and Moldova. 
Graphic 4. Traffic analysis http://www.fluentinfinante.ro/[30]

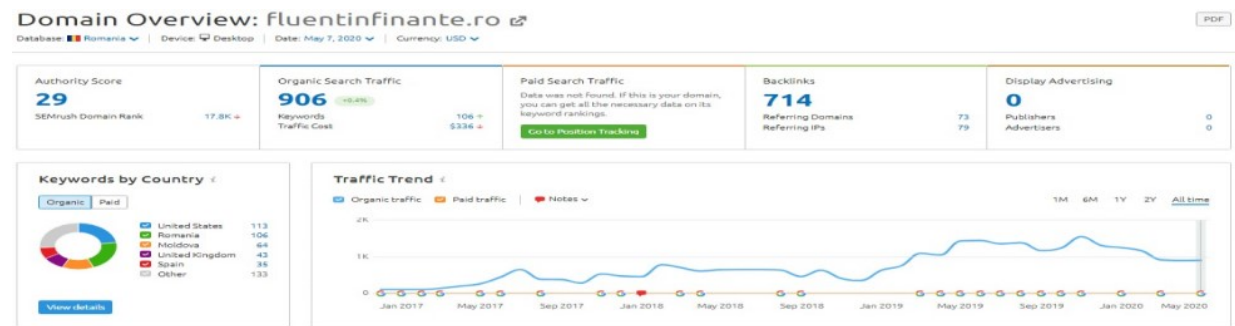

Source: https:// wnw.semrush.com [27]

In Bulgaria, the financial platform is aimed primarily at adults, dealing with issues related to family finances such as making a budget or buying a home through a real estate loan. The main partner of the company that manages the platform is the Financial Literacy Initiative Foundation. The interest of financial consumers in accessing information on this platform has experienced a smooth evolution (graphic 5).

Graphic 5. Traffic analysis for www.semeinifinansi.bg [31]

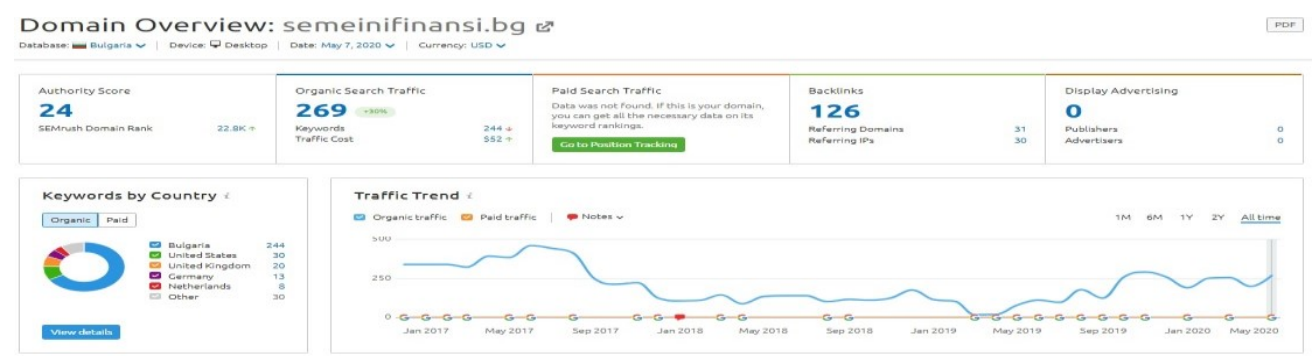

Source: https:// wmw.semrush.com [27]

The launch of the platform was a great success among the population, after which there was a continuous decrease, but the onset of the covid health crisis and its financial implications brought this platform to the attention of financial consumers.

\section{Discussions}

The countries chosen for the study have different approaches regarding the promotion of the concept of financial education through dedicated platforms, being approached with priority or certain areas of interest (family finances)or segments of the population (children and young people). Children and young people should be the most targeted categories 
of the population, considering that in the preschool period and school is formed, the foundations of a long-term sustainable behavior are laid. This trend is in line with the one established by the European Platform for Financial Education set up in 2017 at the initiative of a nine European organizations and associations promotion of financial education and financial literacy in Europe. National Sustainable Development Strategies 2030 in various EU countries aim to increase the level of financial education of citizens and strengthen the capacity of domestic financial institutions to encourage and expand access to banking, insurance and financial services for all. Central and Eastern European countries have begun to use a wide variety of information channels, such as websites, information campaigns, free courses offered by various financial institutions in schools and universities, financial literature, to provide young people and vulnerable categories of consumers who are not included in formal financial markets with comprehensive information on the variety of banking, insurance and financial services available on the market. Efficient budget management is an essential condition for citizens to be able to fulfil their dreams. They need to learn to be aware of their financial decisions, make a personal budget, save and apply smart investment strategies for every age group. The steps taken by financial institutions are particularly important in the context of reduced financial intermediation in the countries of the former communist bloc.

\section{Conclusions}

The responsibility regarding the realization of Financial Education must be divided between parents, school, financial institutions, public institutions with attributions of supervision, regulation and control of the financial market segments, consumer protection authorities, employing companies. Special attention must be paid to children and young people because in the early stages of life are formed consumption and saving behaviors that will later help the adult to establish a sustainable financial behavior that has two balanced segments, namely saving and investing. Moreover, in the context of financial innovation and digitalization, financial behavior must be upgraded. So in the area of financial education, a lifelong learning process that targets both new financial instruments and services and ways of access to them generated by the digitization is necessary. Therefore, the process of financial education acquires new dimensions and values in the digital age.

Financial education also has an important role in restoring consumer confidence in financial institutions. The decline in public confidence in 
credit institutions has been fueled by financial crises triggered by banks through irresponsible or unethical behavior towards clients. In order to maximize their profit, banks have adopted various unethical behaviors such as practicing misleading promotional techniques, abusive contractual clauses by which they took advantage of the lack of financial education, excessive risk exposure by purchasing complex financial assets, which in the end, they turned out to be toxic. A special situation is registered in Central and Eastern Europe. After the fall of communism, the population characterized by a low level of culture became over-indebted, situation fueled by irresistible offers made by banks with foreign capital that made their presence felt in the region after the fall of the communism.

\section{References}

[1] Barberis \& Thaler, R. A survey of behavioral finance. Handbook of the Economics of Finance, 1; 2003: 1053-1128.

[2] Hirshleifer, D. Behavioral finance. Annual Review of Financial Economics, 2015, 7: 133-159.

[3] Lai CP. Personality Traits and Stock Investment of Individuals. Sustainability. 2019; 11(19): 5474.

[4] Matei M, Stancu A, Enesc G, Geambaşu C. Burse de mărfuri şi valori. Ploiesti: Editura Universităţii; 2008

[5] Rjoub H. Stock prices and exchange rates dynamics: Evidence from emerging markets. African Journal of Business Management. 2012; 6(13): 4728-4733.

[6] Grigorescu A, Maer-Matei MM, Mocanu C, Zamfir, AM. Key Drivers and Skills Needed for Innovative Companies Focused on Sustainability. Sustainability. 2020; 12(1): 102.

[7] Matei, M. Responsabilitatea socială a corporațiilor şi instituțiilor şi dezvoltarea durabilă a României. Bucharest: Expert Publishing House; 2013.

[8] Gabor D, Brooks S. The digital revolution in financial inclusion: international development in the fintech era. New Political Economy. 2017; 22(4): 423-436.

[9] Grigorescu A, Cerchia AE, Oachesu MM, Udroiu F. Enhancing Internet Banking-Solutions for Customer Relationship Management. Saudi Journal of Business and Management Studies.2017; 2, (1): 38-43.

[10] Manta O. Innovations in Digital Finance. Journal of Financial and Monetary Economics. 2017; 4(1): 275-279.

[11] Voica, M.C., Financial inclusion as a tool for sustainable development. Romanian Journal of Economics, 2017, 44(1 (53): 121-129.

[12] Ciutacu C, Chivu L, Preda D. The social responsibility of the company-a challenge for the contemporary world. The Romanian Economics Review; 2005, 2: 79 . 
[13] Raimi L, Akhuemonkhan I, Ogunjirin, OD. Corporate Social Responsibility and Entrepreneurship (CSRE): antidotes to poverty, insecurity and underdevelopment in Nigeria. Social Responsibility Journal; 2015.

[14] Brezoi AG. Ethics and Corporate Social Responsibility in the Current Geopolitical Context. Economic Insights - Trends and Challenges. 2018; VII (LXX) No. 2: $45-52$

[15] Palazzo M. Linking Cultural Dimensions and CSR Communication: Emerging Research and Opportunities: Emerging Research and Opportunities, IGI Global; 2019.

[16] Baric A, Omazic MA, Aleksic A, Pejic-Bach M. Influence of CSR Activities on Stakeholders in Foreign Markets. In Recent Advancements in Sustainable Entrepreneurship and Corporate Social Responsibility, IGI Global; 2020: 1636.

[17] Munteanu, I, Grigorescu A, Condrea E, Pelinescu E.Convergent Insights for Sustainable Development and Ethical Cohesion: An Empirical Study on Corporate Governance in Romanian Public Entities. Sustainability, 2020; 12(7): 2990.

[18] Oncioiu I, Petrescu AG, Bîlcan FR., Petrescu M, Fulop MT, Topor, DI. The Influence of Corporate Governance Systems on a Company's Market Value. Sustainability. 2020; 12(8): 3114.

[19] Petrescu, A. G., Bîlcan FR, Petrescu M, Holban Oncioiu I, Turkeş MC, Căpuşneanu S. Assessing the Benefits of the Sustainability Reporting Practices in the Top Romanian Companies. Sustainability, 2020, 12(8), 3470.

[20] Ene C, Panait, M. The financial education-Part of corporate social responsibility for employees and customers. Revista Romana de Economie, 2017, 44(1): 145-154.

[21] Andrei JV, Panait M, Voica C. Challenges and Approaches for the Corporate Social Responsibility and Human Resource Management in the Financial Sector. Economics, Management and Financial Markets; 2018 Sep 1; 13(3): 415-31.

[22] Iacovoiu VB. An Empirical Analysis of Some Factors Influencing Financial Literacy. Economic Insights-Trends and Challenges; 2018, 70(2).

[23] Nicolini, G, Haupt M. The Assessment of Financial Literacy: New Evidence from Europe. International Journal of Financial Studies. 2019; 7(3): 54.

[24] Panait M, Voica MC, Radulescu I. The activity of capital market actors: under the sign of social responsibility. Procedia Economics and Finance. 2014, 8: 522-528.

[25] Ene C. Current Issues Regarding The Protection Of Retail Investors On The Capital Market Within The European Union. The USV Annals of Economics and Public Administration. 2017; 17 (1 (25): 35-44.

[26] Fondazione per l'Educazione Finanziaria e al Risparmio. Available from: www.feduf.it. [Accessed 10.05.2020]

[27] SEMrush. Available from: https://www.semrush.com. [Accessed 10.05.2020] 
Mirela PANAIT et al. | Lumen Proceedings 11 | GEKoS2020

[28] Institute of Financial Literacy. Available from? https://www.gfli.gr [Accessed 10.05.2020]

[29] FinQ. Available at: https://www.finq.sk [Accessed 10.05.2020]

[30] Fluent în finante. Available at: http://www.fluentinfinante.ro/[Accessed 10.05.2020]

[31] Easy Asset Management AD. Available from: www.semeinifinansi.bg [Accessed 10.05.2020] 